\title{
The Effect Of Basic Life Support Training On Basic Life Support Knowledge In 'Aisyiyah Cadre
}

\author{
Dian Yuliartha Lestari ${ }^{1}$, Abi Noerwahjono ${ }^{2}$, Cindy Savira ${ }^{3}$ \\ ${ }^{1}$ Anatomical Pathology Department Medical Faculty, University of Muhammadiyah \\ Malang \\ ${ }^{2}$ Anesthesiology Department Medical Faculty, University of Muhammadiyah Malang \\ 3Student of Medical Education, Medical Faculty, University of Muhammadiyah Malang \\ Email : dianyuliarthalestari@gmail.com
}

Receive : Marc 25th 2020. Revised : May $2^{\text {th }} 2020$. Published: Jun $27^{\text {th }} 2020$

DOI: https://doi.org/10.22219/sm.Vol16.SMUMM1.12718

\begin{abstract}
Background: Basic life support or BLS is an early emergency intervention cases which possibly happens anywhere. BLS is important to be given accurately and immediately not only by healthcare professionals but also by lay people in order to give early intervention towards emergency cases until medical teams arrives. 'Aisyiyah cadre, as part of the society, are expected to be able to give early intervention that is BLS correctly.

Objective: To assess the impact of basic life support training on the knowledge of 'Aisyiyah cadre towards basic life support.

Method: This study is a analytical observational study with cross-sectional approach. The sample of this study is 38 participants which are 'Aisyiyah cadre from Malang city. Participants included on this study are those who do not have any medical background. Data analysis were using wilcoxon test.

Result and discussion: 13 participants were having knowledge improvement, 24 participants did not have any improvements, and one of the participants were having degradation of knowledge level after the BLS training were given. According to wilcoxon test, the p-value was 0,001 which means that the BLS training given have positive impact on the improvement of 'Aisyiyah cadre's knowledge towards BLS.

Conclusion: There is a significant impact between BLS training on the knowledge of 'Aisyiyah cadre towards BLS which indicates that the BLS training given have postivive impact on the improvement of 'Aisyiyah cadre's knowledge towards BLS.
\end{abstract}

Keyword : Basic life support, training, society, cardio pulmonary rescucitation

Copyright (C) 2020, First Author et al This is an open access article under the CC-BY-SA license

\section{INTRODUCTION}

Basic life support or BLS is the first aid in emergency cases that can be happen anywhere. BLS is very important to be done quickly and precisely so that in emergency cases that threaten lives, disability and death can be prevented. Knowledge of BLS is needed for health workers and the community, so that they could provide initial assistance in emergency cases until the medical assistance team arrives. (Meissner et al, 2012); (Can et al, 2019). 
One such emergency is cardiac arrest where the number of cardiac arrest events that occur outside the hospital is recorded at 356,000 lives annually and less than 15 percent survived (Craigbrangan et al, 2019). Other emergency cases that are most often found are trauma due to traffic accidents, anaphylactic shock, and asthma attacks (Luh et al., 2017). Cases of traffic accidents that occurred in Indonesia reached 28,000 in 2014 with the death rate due to traffic accidents amounting to 12 per 100,000 people (Jusuf et al, 2017). Anaphylactic shock cases are rare but life-threatening events, with its rate of 1.5-7.9 per 100,000 people (Patel et al, 2014). Cases of asthma attacks throughout the world are still a major health problem where the prevalence of asthma attacks in Indonesia is under 20 years old (Wahyuni et al, 2018).

'Aisyiyah cadres are cadres from the Aisyiyah women's organization whose activities are to create a healthy society. Aisyiyah cadres as a part of the community has an important role in emergency cases. By providing this BLS training, it is expected that 'Aisyiyah cadres can provide initial assistance in the form of BLS properly if an emergency case is found.

\section{METHODS}

This research was an analytic observational research with cross-sectional or cross-sectional approach because the data collection was done in one time. The sampling technique used was total sampling where all respondents who meet and meet the criteria would be sampled in the study. The research was conducted at the Regional Leadership Office 'Aisyiyah, Malang City, located on Jl. Gajayama No. 28B Lowokwaru District Malang City on July 5, 2019. The data collection instrument was a BLS questionnaire consisting of 17 multiple choice questions. The BLS questionnaire was given before and after the training to assess the increase in knowledge of 'Aisiyah cadres after being given the BLS training.

\section{RESULTS AND DISCUSSION}

Characteristics of respondents in this study were divided into 3 characters namely age, education, and occupation which are listed in the following table:

Table 1. Data Characteristics of Respondents

\begin{tabular}{lccc}
\hline Category & Frequency & Percentage \\
\hline Age & $>25-35$ years old & 3 & $7,9 \%$ \\
& $>35-45$ years old & 12 & $31,6 \%$ \\
& $>45-55$ years old & 15 & $39,5 \%$ \\
& $>55$ years old & 8 & $21,0 \%$
\end{tabular}




\begin{tabular}{cccc} 
Total & & 38 & $100 \%$ \\
\hline \multirow{3}{*}{ Education } & Elementary School & 2 & $5,3 \%$ \\
& Junior High School & 2 & $5,3 \%$ \\
Total & Senior High School & 16 & $42,0 \%$ \\
Occupation & Bachelor & 18 & $47,4 \%$ \\
& Housewife & 38 & $100 \%$ \\
\hline Total & Retired civil servant & 21 & $55,3 \%$ \\
& Entrepreneur & 1 & $2,6 \%$ \\
& Teacher & 7 & $18,4 \%$ \\
& & 9 & $23,7 \%$ \\
\hline
\end{tabular}

To find out the distribution of knowledge enhancement in each characteristic, the following table shows the cross distribution data for each characteristic with the knowledge categories before (pre) and after (post) training:

Table 2. Cross Tabulation of Characteristics of Respondents on Knowledge Level

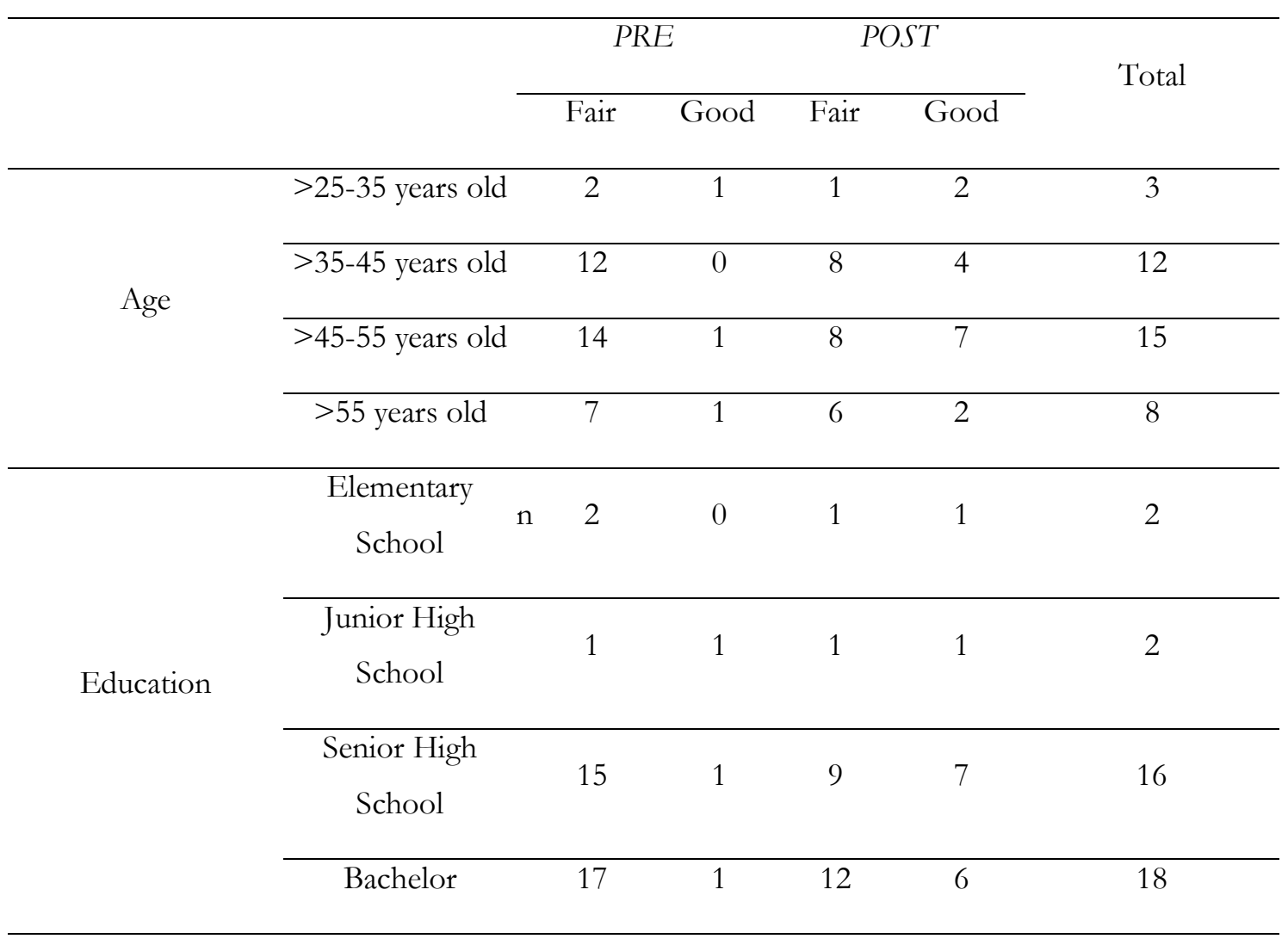




\begin{tabular}{ccccccc}
\hline & Housewife & 18 & 3 & 10 & 11 & 21 \\
\cline { 2 - 6 } Occupation & Retired civil & 1 & 0 & 1 & 0 & 1 \\
& servant & & & & & 7 \\
\cline { 2 - 6 } & Entrepreneur & 7 & 0 & 6 & 1 & 9 \\
\hline
\end{tabular}

To find out the relationship between these three characteristics to the increase of BLS knowledge in Aisyiyah cadres, a Kruskal-wallis test was performed and the following results were obtained.:

Table 3. Wilcoxon Test

\begin{tabular}{|c|c|c|c|c|c|c|}
\hline & & \multicolumn{3}{|c|}{ Post } & \multirow{2}{*}{$P$ - Value } & \multirow{2}{*}{ Significance } \\
\hline & & Poor & Fair & Good & & \\
\hline & Poor & 0 & 0 & 0 & & \\
\hline \multirow[t]{2}{*}{ Pre } & Fair & 0 & 22 & 13 & 0,001 & Significant \\
\hline & Good & 0 & 1 & 2 & & \\
\hline
\end{tabular}

Table 3 shows that the p-value is 0.001 or significant, which means that the BLS training in this study that was given to Aisyiah cadres had a significant effect on increasing BLS knowledge in Aisyiyah cadres. Increased BLS knowledge occurred in 13 respondents where the level of pre knowledge was fair and the level of post knowledge was good.

In the Wilcoxon test, which aims to assess the effect of BLS training on increasing BLS knowledge in Aisyiyah cadres, the following results were obtained:

Table 4. Kruskal-wallis Test Characteristics of Respondents on Knowledge Level

\begin{tabular}{lccl}
\hline Characteristics & $\begin{array}{c}\text { Significance of } \\
\text { "Pre" Knowledge } \\
\text { Level }\end{array}$ & $\begin{array}{c}\text { Significance of } \\
\text { "Post" Knowledge } \\
\text { Level }\end{array}$ & Relationship \\
\hline Age & 0,257 & 0,510 & Not related \\
Education & 0,153 & 0,856 & Not related \\
Occupation & 0,463 & 0,260 & Not related \\
\hline
\end{tabular}


From the results of the kruskal-wallis test it was found that the three characteristics of the respondents mentioned above did not have a relationship to the respondents' level of BLS knowledge both at the pre and post level of knowledge.

From the kruskal-wallis test that the age characteristics obtained significance values of the level of pre knowledge of 0.257 and post of 0.510 . These data indicate that there is no significant relationship of the age factor on the level of knowledge in this BLS training. This result is different from the study conducted by Jin et al (2016) with 502 respondents who were given BLS training and stated that there was a significant relationship between age and level of knowledge of BLS. This difference is due to the limited number of respondents in this study, which is only 38 respondents and dominated by the age 45-55 years old category (variation in the age category of respondents was lacking).

From the kruskal-wallis test on the characteristics of education, the results obtained at the level of pre knowledge have a significance value of 0.153 and post of 0.856 . This result means that there is no relationship between education level and increasing knowledge in BLS training. It is in line with a research done by Subki et al in Interactive Journal Medical Research which states that the level of individual education is not related to the level of BLS knowledge (Subki et al., 2018). This study has similarity that the majority of the education level of the respondents are bachelor graduates. Subki et al said that the level of education did not affect the increase in BLS knowledge because BLS knowledge could be obtained from various information media.

From the kruskal-wallis test on the characteristics of work, the results obtained significance value at the level of pre knowledge of 0.463 and post of 0.260 . This shows that there is no relationship between occupation and knowledge increasing at the time of training. In line with Shrestha et al's research in the Journal of the Nepal Medical Association which states that occupation is not related to the level of BLS knowledge (Shrestha et al., 2018). This research and Shrestha research have in common that both agree that the presentation of BLS material conducted during training greatly affects the increase in BLS knowledge regardless of the respondent's occupation background.

\section{CONCLUSION}

The conclusion obtained from the results and discussion above is that there is a significant effect of BLS training on knowledge about BLS in Aisyiyah cadres where the increase in respondent's knowledge in this study is not related to the characteristics of age, education, or occupation of the respondent.

\section{REFERENCES}

Can, N., \& Çi, İ. (2019). Turkish Journal of Emergency Medicine The evaluation of laypersons awareness of basic 
life support at the university in Izmir. 19(January), 26-29. https://doi.org/10.1016/j.tjem.2018.11.002

Craig-brangan, B. Y. K. J., \& Day, M. P. (2019). Update: 2017 / 2018 AHA BLS, ACLS, and PALS guidelines. 49(2), 2017-2020.

Jusuf, A., Nurprasetio, I. P., \& Prihutama, A. (2017). Macro data analysis of traffic accidents in Indonesia. Journal of Engineering and Technological Sciences, 49(1), 133-144. https://doi.org/10.5614/j.eng.technol.sci.2017.49.1.8

Lee, J. H., Cho, Y., Kang, K. H., Cho, G. C., Song, K. J., \& Lee, C. H. (2016). The Effect of the Duration of Basic Life Support Training on the Learners ' Cardiopulmonary and Automated External Defibrillator Skills. 2016.

Luh, N., Inca, P., Agustini, B., Putu, I. G., Suyasa, D., Treesna, N., .. Rismawan, M. (2017). Penyuluhan dan Pelatihan Bantuan Hidup Dasar. 1(2), 68-74.

Meissner, T. M., Kloppe, C., \& Hanefeld, C. (2012). Basic life support skills of high school students before and after cardiopulmonary resuscitation training: A longitudinal investigation. Scandinavian Journal of Trauma, Resuscitation and Emergency Medicine, 20, 1-7. https://doi.org/10.1186/1757-7241-20-31

Patel, T. K., Patel, P. B., Barvaliya, M. J., \& Tripathi, C. B. (2014). Drug-induced anaphylactic reactions in Indian population: A systematic review. Indian Journal of Critical Care Medicine, 18(12), 796-806. https://doi.org/10.4103/0972-5229.146313

Shrestha, R., Shrestha, A., Batajoo, K. H., Thapa, R., Acharya, S., Bajracharya, S., \& Singh, S. (2018). An experience of video based training on basic life support. Journal of the Nepal Medical Association, 56(212), 774-780. https://doi.org/10.31729/jnma.3645

Subki, A. H., Mortada, H. H., Alsallum, M. S., Alattas, A. T., Almalki, M. A., Hindi, M. M., ... Sulaymaniyah, A. (2018). Basic Life Support Knowledge Among a Nonmedical Population in Jeddah , Saudi Arabia: Cross-Sectional Study Corresponding Author: 7, 1-9. https://doi.org/10.2196/10428

Wahyuni, A. S., Hamid, R. Z., Syafiuddin, T., Bachtiar, A., \& Nerdy, N. (2018). The correlation between adherence and asthma patients quality of life in Medan, Indonesia. Open Access Macedonian Journal of Medical Sciences, 6(11), 2198-2205. https://doi.org/10.3889/oamjms.2018.362 